\section{Estudo \\ CoDebate}

em Testão

Plamejamento
Revista Estudo \& Debate, Lajeado, v. 24, n. 2, 2017. ISSN 1983-036X

DOI: http://dx.doi.org/10.22410/issn.1983-036X.v24i2a2017.1254

\title{
ANTHRACOLOGICAL EVALUATION AT ARCHAEOLOGICAL SITES OF GUARANI OCCUPATION - TAPHONOMIC COMPARISONS TO CONSTRUCT THE ENVIRONMENTAL HISTORY OF THE FORQUETA RIVER BASIN, RS, BRAZIL
}

\author{
Mariela Inês Secchi ${ }^{1}$, Isa Carla Osterkamp ${ }^{2}$, Marjorie Kauffmann ${ }^{3}$, Joana Beuren ${ }^{4}$, \\ Neli Teresinha Galarce Machado ${ }^{5}$, Daniel Martins dos Santos ${ }^{6}$, \\ Soraia Girardi Bauermann ${ }^{7}$, André Jasper ${ }^{8}$
}

\begin{abstract}
Anthracological studies aim at the reconstruction of the paleoenvironment through the analysis and interpretation of macroremains of carbonized woods found in soils and archaeological sites that are related to previous human activities. The objective of this study was to compare the anthrocological and taphonomic data of the Archaeological Sites RS-T-101 and RS-T-114, located in the municipality of Marques de Souza, associated with pre-colonial occupancies of Guarani origin (archaeological sites RS-T-114 and RS-T-101, respectively, in 1,410-431 BP years and 1,411 -295 years BP, to build the environmental history of the Forqueta River basin based on taphonomic comparisons between these two sites. The traces analyzed were collected following methodology scaling and blasting, being conducted by the Archeology Section of the team's Museum of Natural Sciences of the UNIVATES University Center. In this work, the images of carbon obtained under SEM were analyzed from both sites, which were the object of previous anthrachological studies, being used to perform the taphonomic comparisons. From the images, it can be inferred that the recovered charcoals in
\end{abstract}

1 Programa de Pós-Graduação em Ambiente e Desenvolvimento, da Univates. Setor de Paleobotânica e Evolução de Biomas Terrestres. maries@universo.univates.br

2 Programa de Pós-Graduação em Ambiente e Desenvolvimento, da Univates. Setor de Paleobotânica e Evolução de Biomas Terrestres. isaosterkamp@hotmail.com

3 Setor de Paleobotânica e Evolução de Biomas Terrestres. marjoriekauffmann@yahoo.com.br

4 Setor de Paleobotânica e Evolução de Biomas Terrestres. jbeuren@universo.univates.br

5 Programa de Pós-Graduação em Ambiente e Desenvolvimento, da Univates. Setor de Arqueologia do Museu de Ciências Naturais da Univates. nelitgm@yahoo.com.br

6 Setor de Ecologia e Sensoriamento Remoto do Museu de Ciências Naturais da Univates. dsantos1@universo.univates.br

7 Laboratório de Palinologia da Universidade Luterana do Brasil - ULBRA. soraia.bauermann@ulbra.br

8 Programa de Pós-Graduação em Ambiente e Desenvolvimento, da Uunivates. Setor de Paleobotânica e Evolução de Biomas Terrestres. andrejasper@univates.br 
the sites had their anatomical characteristics well preserved, being possible to observe homogenization of the cellular walls, as well as the thickness of the walls demonstrates fires with temperatures that did not exceed $340^{\circ} \mathrm{C}$. Moreover, with this study it was possible to infer that the fragments found in these sites may have been originated by fires of anthropogenic origin because they are dispersed in the sedimentary matrix as well as in places with the presence of vestiges of fires.

Keywords: Anthracology. Wood charcoal. Taphonomy. Archaeobotanical analysis.

Resumo: Avaliação antracológica em sítios arqueológicos de ocupação Guarani -comparaçôes tafonômicas para construir a história ambiental da bacia do Rio Forqueta, RS, Brasil. Os estudos antracológicos visam à reconstituição do paleoambientepor meio da análise e interpretação de macrorestosde madeiras carbonizadas encontradas em solos e sítios arqueológicos que se relacionam com atividades humanas pretéritas. O objetivo deste estudo foi comparar os dados antracológicos dos Sítios Arqueológicos RS-T-101 e RS-T-114, localizados no município de Marques de Souza, associados a ocupaçôes pré-coloniais de origem Guarani (sítio arqueológico RS-T-114 e RS-T-101 datados, respectivamente, em 1.410-431 anos AP e 1.411 AP - 295 anos AP. para construir a história ambiental da bacia do Rio Forqueta baseado em comparaçôes tafonômicas entre os sítios. Os vestígios analisados foram coletados seguindo-se metodologia de escalonamento e decapagem, sendo realizada pela equipe do Setor de Arqueologia do Museu de Ciências Naturais do Centro Universitário UNIVATES. Neste trabalho, foram analisadas as imagens de carvão obtidas sob MEV de ambos os sítios, as quais foram objeto de estudos antracológicos anteriores, sendo utilizadas para realização das comparaçôes tafonômicas. A partir das imagens, pode-se inferir que os carvões recuperados nos sítios tiveram suas características anatômicas bem preservadas, sendo possível observar homogeneização das paredes celulares, bem como a espessura das paredes demonstra fogos com temperaturas que não excederam $340^{\circ} \mathrm{C}$. Além disso, com este estudo foi possível inferir que os fragmentos encontrados nesses locais podem ter sido originados por incêndios de origem antropogênica por estarem dispersos na matriz sedimentar bem como em locais com a presença de vestígios de fogueiras.

Palavras-chave: Antracologia. Carvão Vegetal. Tafonomia. Análises Arqueobotânicas.

\section{INTRODUCTION}

Anthracology is part of a multi-disciplinary field of study, which aims to replenish the (palaeo)environment through the analysis and interpretation of macro-charred remains of wood or other plant material, from soil or archaeological sites (VERNET, 1992; GONÇALVES, 2006; SCHEEL-YBERT et al., 2010).

The charred wood fragments (charcoal) collected in archaeological context, provide, in addition to the possibility of reconstruction of palaeoenvironment, important palaeoetnobotanical information, since they contribute to a better understanding of the landscape and the use of plants by the preterit communities, and help to provide direct evidence of the relationship between man and his environment (GONÇALVES et al., 2005).

These data allow for a better interpretation of the ways of life of these human communities, the available environmental resources, the influence of population on the environment and the influence of the environment on the people (SCHEEL-YBERT, 2004; SCHEEL-YBERT et al., 2010).

According to Scheel-Ybert et al. (2006), with the analysis of retained sediment carbon fragments is possible to portray the vegetation that was found in the vicinity of the site during the occupation period, since the plant material combustion is one of the most frequent elements at archaeological sites (YBERT-SCHEEL et al. 2003; 2006). 
Macroscopic charcoal is the result of the partial combustion of wood (Scott, 2000, 2010), which can be both voluntary and accidental. According to Mateus (1996) and Scheel-Ybert (2000), the charcoal found next to the archaeological sites can be associated with the routine of community activities, such as the emptying of a fire (used for ritual contexts, for cooking food or heating), the overthrow of structures, among other activities.

Studies by Haberle et al. (2001) show that the charcoal preserved in soils, lakes and sediment samples has been used to investigate the fire records of the past, and is considered an important tool to assist in the analysis of changes in the ecosystem where the preterit populations lived or with which it is related. In addition, Mateus and Moreno-Garcia (2003) infer that the conservation of woody tissues through partial carbonization in fires and other combustion structures built by the people of the past, as well as the accidental carbonization in the form of natural fires, are important sources of palaeoecological information and archaeobotany. The authors also comment that the identification of woody flora used by these populations in addition to serving as a database on the use of plant resources by communities, serves also to elucidate what were the plant species occurring in certain territories in the past (MATEUS; MORENO-GARCIA, 2003).

For a better understanding of environmental issues, relations with the pre-colonial studies in human groups allied with archaeological sites should be done in a multidisciplinary way. Therefore, this study aimed, through an archaeobotanical perspective (anthracological analysis), at comparing taphonomically the archaeological sites RS-T-101 and RS-T-114. The findings will contribute to archaeobotanical and paleoenvironmental studies later for the study areas. In addition, this work contributes to management actions of the archaeological sites of the Vale do Taquari region, since only with past knowledge can we plan actions for the purpose of protecting the regional archaeological heritage.

\section{STUDY AREA}

The Archaeological Sites RS-T-101 and RS-T-114 are located in Marques de Souza municipality, in the localities of Linha Tamanduá and Linha Bastos, respectively, Rio Grande do Sul State, Brazil. Both locations are embedded in the political area of the Taquari Valley, Forqueta River Basin, and are situated between the geographic coordinates UTM SAD $69-387480 \mathrm{~L}$ and $676347 \mathrm{~N}$ (RS-T-101) and 391253L and 679521N (RS-T-114) (Fig.1). 
Figure 1 - Location of Taquari Valley, where the Forqueta River Basin is practically all embedded in state context of Rio Grande do Sul

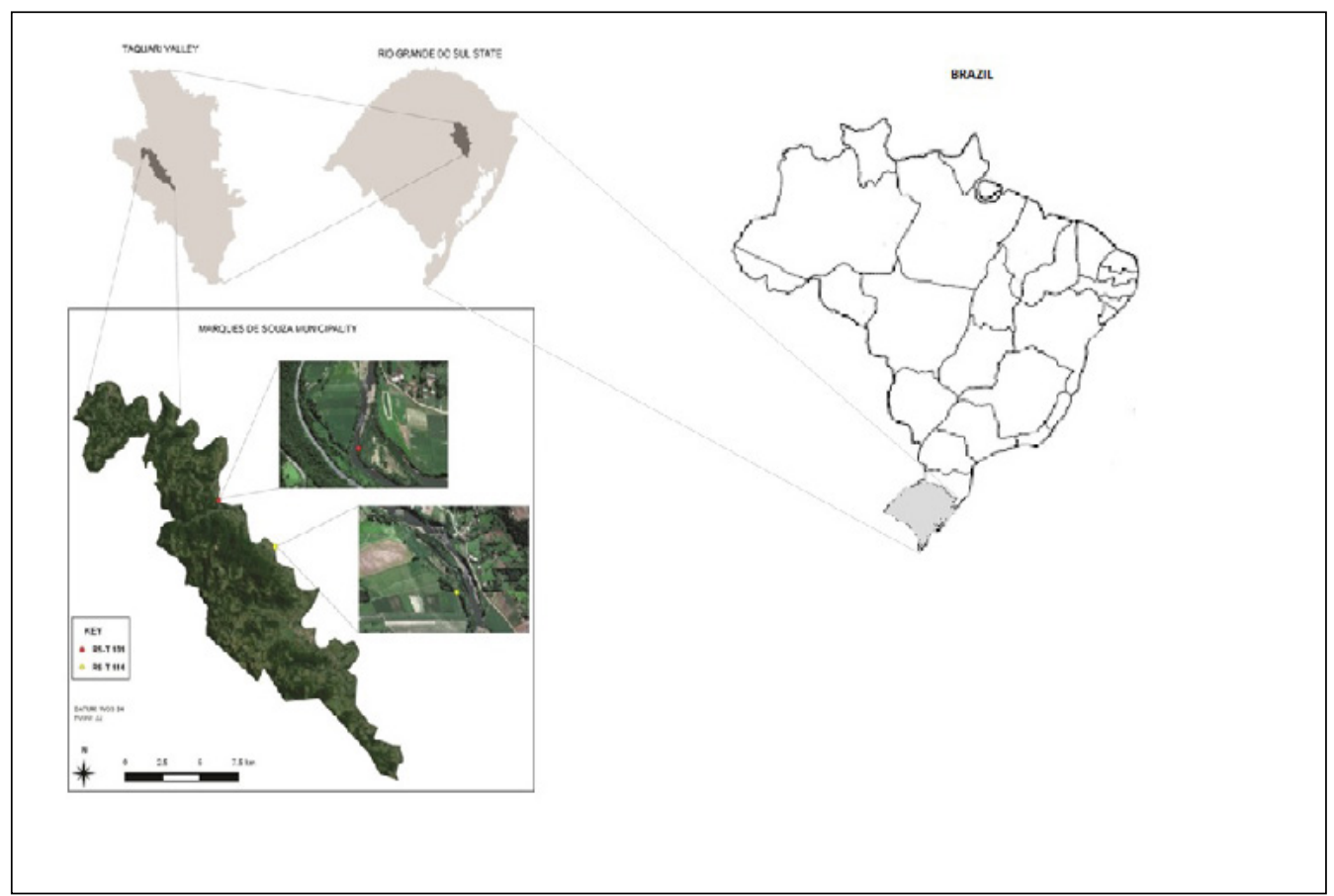

Source: Elaborated by authors.

The work carried out for the region of Forqueta River Basin was mostly directed to the archaeological knowledge, given the existence of several sites registered close to that were the subject of this study.

Among the sites that have already been present in published studies of archeology are: RS-T-101, RS-T-107, RS-T-110, RS-T-114, in those areas were developed studies on the occupation of pre-colonial groups of Guarani source and were found lithic materials as well as their possible manufacturing areas (Machado; Milder, 2005; Kreutz, 2008; Schneider, 2008; Fiegenbaum, 2009; Wolf, 2010; 2012). Of all these sites, studies of anthracological character were performed only for RS-T-114 and RS-T-101(SCHMIDT, 2010; BEUREN et al., 2012; SECCHI, 2012).

\section{MATERIAL AND METHODS}

For this study we analyzed the images and fragments of charcoal samples from archaeological sites RS-T-114 and RS-T-101. The images were obtained from electron microscopy, made by Schmidt (2010) and Beuren et al. (2012), respectively.

The archaeological sites RS-T-114 and RS-T 101 are dating through the method of thermoluminecense analysis, resulting in ages, respectivally, of 1,410-431 years BP and 1,411 AP - 295 years BP. 
Were analysed in the both sites some criteria, like: the location of charcoal fragments in archaeological context; presence or absence of fungal hyphae attached in wall cells of the carbonized samples; dating the data analysed; cell wall thickness (fire intensity). These criteria are important to make taphonomic inferences to construct the history of the area.

The images of the carbonized fragments of both sites were compared based on the reference bibliography in plant anatomy (Wheeler et al., 1989) for purposes of morphological and anatomical comparison, and intersites comparison.

\section{RESULTS AND DISCUSSION}

Based on studies of Schmidt (2010), Beuren et al. (2012) and Secchi (2012) the fragments found in the sediment collected on the Sites RS-T-101 and RS-T-114 can be classified as macroscopic charcoal, as described by Jones and Chaloner (1991), Scott (1989; 2010) and Scott and Glasspool (2007). Samples have the macroscopic (Fig.2) [black color and silky luster] and microscopic characteristics [homogenized cell walls and well preserved cellular structures] as defined elaborated by these authors.

Figure 2 - Macroscopic charcoal from the Archaeological Site RS-T-101 of Taquari Valley, Rio Grande do Sul

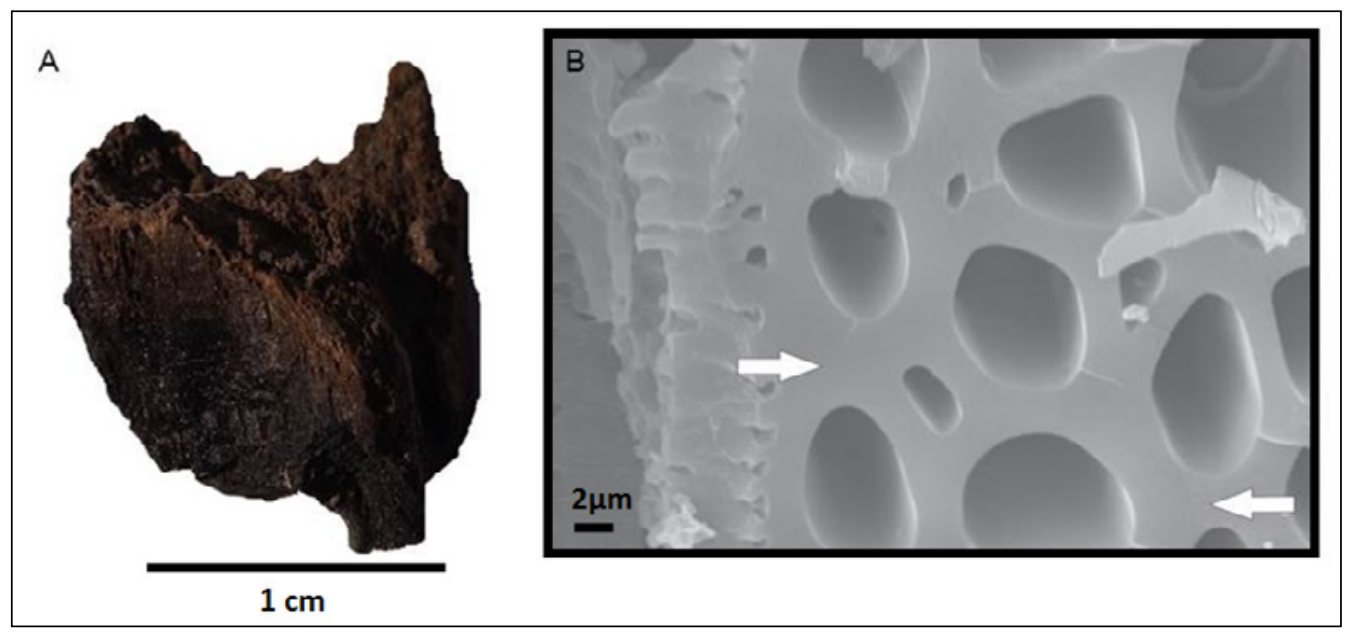

Source: Collection of Botany and Paleobotany Department of the Natural Sciences Museum of UNIVATES University Center.

Legend: A - macroscopic characteristics - black color and silky luster; B - microscopic characteristics homogenized cell walls (arrows).

According to Chabal et al. (1999), the taxonomic identification of charcoal depends on the anatomical characteristics of each species, the size of the charred fragment and its state of preservation. As the analyzed fragments had their preserved cellular structures, one can conclude that samples of both sites had angiospermic affinities.

Moreover, it was possible to identify in the samples, cellular structures such as vessel elements, pits, radial cells, perforation plates and parenchyma cells (Fig.3), but it was not 
possible to identify the botanical family that the samples belonged to. One can observe also that the cell walls were homogenized and, in some samples, it was observed the presence of fungal hyphae.

Figure 3 - Scanning Electron Microscope images of charcoal
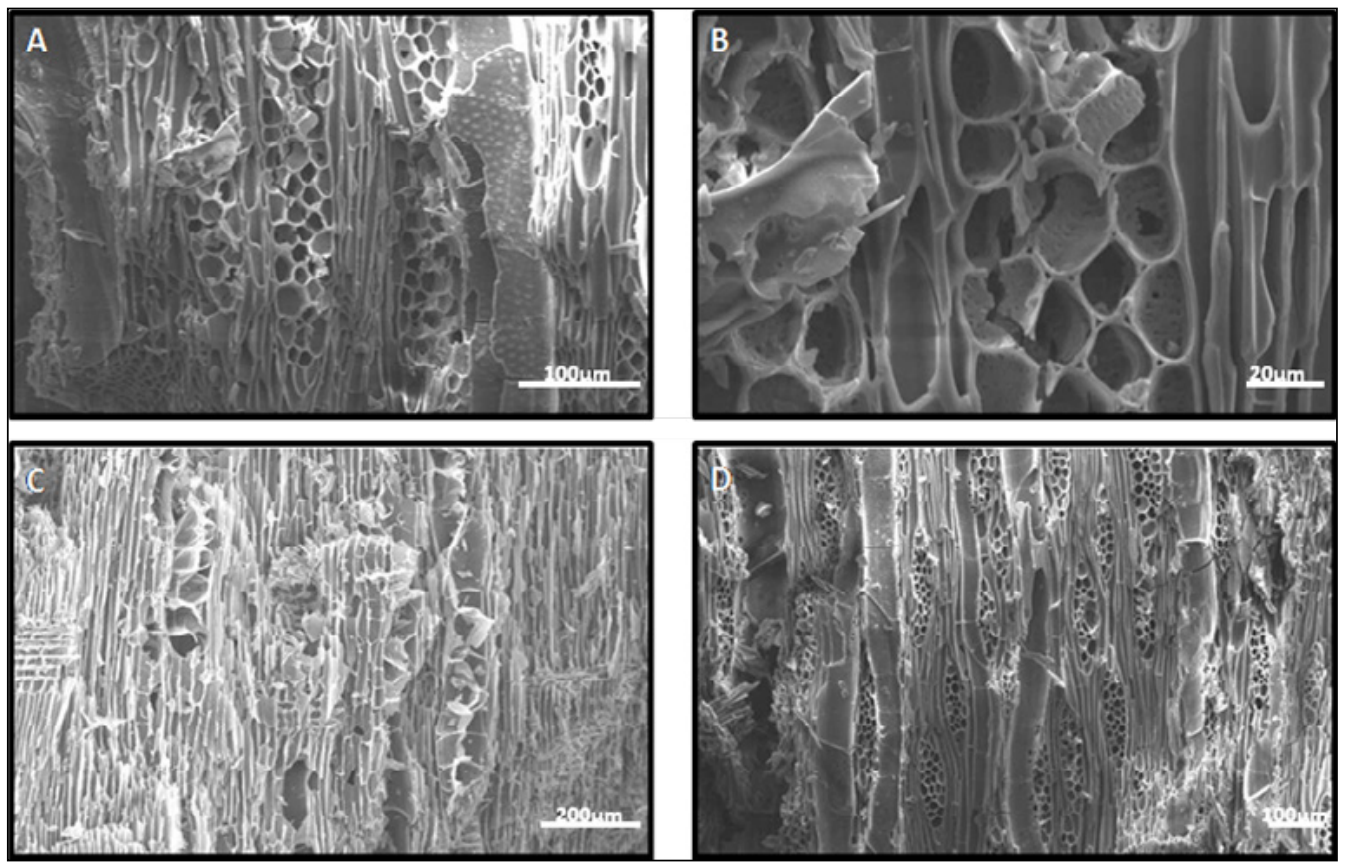

Source: Elaborated by authors.

Legend: A: rays cells, vessel and intervessel pits. B: Detail of rays cells in tangential longitudinal section. C: ray cells and vessel elements in radial section. D: ray cells and vessel elements, in tangential section

Authors like Schweingruber (1982), Théry-Parisot (2001), Hoyo et al. (2010) confirm, in their works, which hyphae of fungi and other structures produced by microorganisms can be preserved in charcoal fragments after the firing process. This can assist in providing evidence regarding the relationship of past populations and the environment around them.

The presence of the hyphae was observed in only one of the samples of the Site RS-T101 analyzed under SEM (BEUREN et al., 2012), differing data found by Schmidt (2010) that all the samples contained fungal contamination.

The occurrence of fungal hyphae in the charred wood analyzed by Schmidt (2010) provides a discussion on the use of dead-wood by the Guarani groups that lived on site RS-T-114, whereas the author did an analysis of important palaeoetnographic character, it demonstrated the kind of behavior of this group in relation to the site's surrounding vegetation.

The author states that "the use of dead wood was, if not a constant, a fairly significant trend" (SCHMIDT, 2010, p. 90) for these pre-colonial populations. This suggests that there was much plant material available in the environment; and that it was not necessary 
to cut living plants (cutting of forest species) for the different activities in which they were used.

As for the geographical distribution of charcoal fragments on the Sites RS-T-101 and RS-T-114, this is distinct in both locations. While charcoal fragments of the Site RS-T-114 were found in two areas (area 1 - disposal area and area 2 - housing area (Fiegenbaum, 2009; Schmidt, 2010) and all stratigraphic, on the site RS-T-101 only one place was identified with presence of carbonized plant material (BEUREN et al., 2012) and only two stratigraphic levels.

With this data we can infer that the pre-colonial populations, inhabitants of the site RS-T-114, possibly only collected dead plants in the vicinity of the site, while for the site RS-T-101, the collection of such material may have been sporadic, since this procedure is not shown.

It is assumed that the preterit people did not choose only certain plant species to use in their daily activities, randomly collecting wood available in the environment, which depended also on factors such as the abundance of wood in the environment, difficulty to collect and transport capacity of these materials (Hoyo et al., 2010). The collection of vegetables could be based on an assessment of the effort required to collect the wood rather than an intentional selection, where a few particular species would be collected (SHACKLETON; PRINS, 1992; HOYO et al., 2010).

Regarding the origin of the charred material, it was not possible to observe the characteristic of the fragments edges because they were rounded or too fragmented. It can be inferred that the charred wood originated in situ, and was not transported to the site. Also the charred material was found next to the black earth at both sites, which corroborates this idea.

Fragments of both sites were sent for radiocarbon dating. This technique is the most widely used method for dating archaeological studies in the recent Quaternary (SCHEELYBERT, 1999). According to Coelho (2012), the material most often used to make dating by ${ }^{14} \mathrm{C}$ technique is charcoal, but any other organic material can be used (such as wood, bone, sediment, shells). This technique, according to Scheel-Ybert (1999), "is ideal for dating the events connected with the history of man from the Paleolithic to the historical era."

The charcoal samples from the site RS-T-101 were sent to Beta Analytic Radiocarbon Dating Laboratory (Miami/Forida/US) to dating, resulting in the age of $370 \pm 30 \mathrm{AP}$ [Beta326926] (BEUREN et al., 2012). The result of the analysis by this method reveals that the occupation of this site was recent, in other words, a few centuries before European immigration to Forqueta River Basin.

Also samples of charcoal from the two distinct areas were sent (disposal area - Area 1 and housing area - Area 2) of the Site RS-T-114 (KREUTZ, 2008; FIEGENBAUM, 2009; SCHMIDT, 2010). The dating of fragments resulted in the ages of $300 \pm 30 \mathrm{BP}$ (Beta303992 - Area 1) and $410 \pm 30$ BP (Beta-326927 - Area 2). Studies by Fiegenbaum (2009) had already dated charcoal fragments of the Area 1 by the same method, resulting in an age of $560 \pm 40 \mathrm{BP}($ Beta-249391). 
Analysis of charcoal fragments confirms the dating carried out by thermoluminescence method (TL) to the ceramic samples collected at both sites. The ceramics of the Site RST-101, object of a study carried out by Schneider (2008), was analyzed in Laboratório de Cristais Iônicos, Filmes Finos e Datação - Universidade de São Paulo (LACIFID), resulting in a maximum age of 1,099 years. Studies by Watanabe et al. (2009), with TL dating of other ceramic fragments from this same site, were between 1,411 AP - 295 AP.

As for the site RS-T-114, the dating of ceramic showed that the period of occupation of this area happened between VI and XVI centuries (MACHADO, 2007; KREUTZ, 2008). The ceramic from this site was also dated by the TL by LACIFID/USP, where it was found that older samples were 1,410 years old, while the most recent were around 431 years old (WATANABE et al., 2009).

\section{CONCLUSIONS}

From the data found in the present study, we are able to make the following conclusions:

(1) All wood collected in the site RS-T-101 has angiospermic affinities as well as those found in the site RS-T-114, in a study by Schmidt (2010). Furthermore, coals collected from both locations may also be considered macroscopic charcoal, in accordance with the characterization made by Jones and Chaloner (1991) and Scott $(1989,2010)$.

Given the strongly generalist condition regarding the taxonomic group represented by the archaeological charcoal in this study, it is recommended that a more detailed anatomical analysis and taxonomy be undertaken in order to better recognize the taxa recovered in these archaeological sites.

(2) Unlike the studies by Schmidt (2010), fungal hyphae was found in only one of the samples of macroscopic charcoal from the site RS-T-101, while for the site RS-T-114, all samples of macroscopic charcoal contained traces of these microorganisms.

According to the same author, the presence of this type of structure in all samples allows us to infer that the inhabitants of the site RS-T-114 were either collecting dead wood lying on the forest floor or they were in life position, but already had some degree of decomposition. The same can not be said for the site RS-T-101. Since only one sample contained these structures, it can be inferred that the collection of dead plants was unusual.

The preterit populations could make forest management, as mentioned by Noelli (1996) and Dias (2003).

(3) The period of occupation of the site RS-T-101, according to the datings by TL of ceramics and ${ }^{14} \mathrm{C}$ of macroscopic charcoal fragments found in the area, was between the ages VI and XIX, while for the site RS-T-114, the occupation took place between centuries VI and XVIII.

(4) The temperature of the combustion plant material on both sites did not exceed $340^{\circ} \mathrm{C}$. This can be realized by the thickness of the cell walls, once the temperature was higher, the cell wall was thinner and could be fragmented (JONES; CHALONER, 1991). 
(5) Further studies are needed for the region, although the anthracological analyzis assists in understanding the relationship between the pre-colonial populations and preterit flora. In addition, this work contributes to the management of archaeological sites in the Taquari Valley region, as it is only through past knowledge that strategies can be designed to protect the regional archaeological heritage.

\section{ACKNOWLEDGEMENTS}

We thank to Capes/PROSUP for financing the study with $\mathrm{PhD}$ fellowship, and also to Fapergs, CNPq, Univates for supporting the development of this study. A. Jasper thanks CNPq for the Research Productivity Scholarship.

\section{REFERENCES}

BEUREN, J.; SECCHI, M.I.; JASPER, A.; WOLF, S.; MACHADO, N.T.G. Análise de carvão vegetal macroscópico em porçóes do Sítio Arqueológico RS-T-101, Marques de Souza/Rio Grande do Sul, Brasil. Caderno de Pesquisa. Santa Cruz do Sul. v. 24, n. 3, p. 24-37. 2012.

CHABAL, L.; FABRE, L.; TERRAL, J-F; THÉRY-PARISOT, I.LAAnthracologie. In: Ferdière A, Bourquin-Mignot CH, Brochier J-E, Chabal L, Crozat S, Fabre L, Terral J-F, Théry-Parisot I. (Eds.) La Botanique. Collection “Archéologiques”. Ed. Errance, Paris, p. 43-104.

COELHO, J.M. Dataçáo em Arqueologia. Available in: http://professor.ucg.br/ siteDocente/admin/arquivosUpload/13070/material/aplica\%C3\%A7\%C3\%A3odata\%C3\%A7\%C3\%A3o\%20por\%20carbono\%2014(1).pdf>, Access: 02/25/2016. 2012

DIAS, A.S. Sistemas de assentamento e estilo tecnológico: uma proposta interpretativa para a ocupaçáo pré-colonial do Alto Vale do Rio dos Sinos, Rio Grande do Sul. PhD Thesis, Faculdade de Filosofia, Letras e Ciências Humanas, Universidade de São Paulo, São Paulo. 2003. Available in: <http://www.teses.usp.br/teses/ disponiveis/8/8153/tde-21102004-162152/>. Access: 03-10-2016.

FIEGENBAUM, J. Um Assentamento Tupiguarani no Vale do Taquari/RS. Masters Dissertation. Unisinos, São Leopoldo. 2009.

GONÇALVES, T.A.P. Contribuição ao conhecimento da anatomia da Madeira das famílias Anacardiaceae, Annonaceae, Aquifoliaceae, Apocynaceae e Araliaceae, através de amostras carbonizadas do lenho de espécies brasileiras. GraduateThesis Universidade Federal Rural do Rio de Janeiro. 116p. 2006. 
GONÇALVES, T.A.P.; ZBOROWSKI, M.B.; SCHEEL-YBERT, R.. In: Resumos expandidos, X Cong. Bras. da Assoc. Bras. de Estudos do Quaternário, 4p (CD-Rom). 2005.

HABERLE, S.G.; HOPE, G.S.; VAN DER KAARS, W.A. Biomass burning in Indonesia and Papua New Guinea: natural and human induced fire events in the fossil record. Palaeo 3, 171, 259-268. 2001.

HOYO, M.M-DEL; WACHOWIAK, M.; BLANCHETTE, R.A. Preservation of fungi in archaeological charcoal. Journal of Archaeological Science, 37, 2106-2116. 2010.

JONES, T.P; CHALONER, W. Charcoal, its recognition and palaeoatmospheric significance. Paleo3, Volume 97, Issues 1-2, Pages 39-50. 1991.

KREUTZ, M.R. O contexto ambiental e as primeiras ocupaçóes humanas no Vale do Taquari - Rio Grande do Sul. Masters Dissertation - Univates. 150 p. 2008.

MACHADO, N.T.G. Análises e perspectivas geoambientais da arqueologia e seus reflexos na cultura humana do Vale do Taquari-RS. Lajeado: Projeto de Pesquisa, Propex, UNIVATES. 2007.

MACHADO, N.T.G; MILDER, S.E.S. Prospecçóes arqueológicas e físico-químicas no sítio RS-T 100: estruturas em San Valentin - Ilópolis-RS. In: MILDER, Saul Eduardo Seiguer (Org.) Anais do I Colóquio sobre Sítios Construídos: casas subterrâneas. Santa Maria: Pallotti.

MATEUS, J.A. Arqueologia da Paisagem e Paleoecologia. Almadán, II série, no 5 "Especial Ciência”. 2005.

MATEUS, J.E.; MORENO-GARCÍA, M. Paleoecologia Humana e Arqueociências: Um programa multidisciplinar para a Arqueologia sob a Tutela da Cultura. Trabalhos de Arqueologia 29. Instituto Português de Arqueologia. ISSN 0871-25, ISBN 972-866213-0. 2003.

NOELLI, F.S. Os Jê do Brasil Meridional e a antiguidade da Agricultura: Elementos da linguística, arqueologia e etnografia. Estudos Ibero-Americanos. PUCRS, v. XXII, n. 1, p. 13-25. 1996.

SCHEEL-YBERT, R. Vegetation stability in the southeastern Brazilian coastal area from 5500 to $1400{ }^{14} \mathrm{C}$ yr BP deduced from charcoal analysis. Rev. of Palaeobotany and Palynology, v. 110, p. 111-138. 2000.

SCHEEL-YBERT, R. Man and vegetation in the Southeastern Brazil during the Late Holocene. Journ. Of Archaeological Science, v. 28, n. 5, p. 471-480. 2001. 
SCHEEL-YBERT, R. Teoria e métodos em antracologia. 1. Consideraçóes teóricas e perspectivas. Arquivos do Museu Nacional, Rio de Janeiro, v. 62, p. 3-14. 2004.

SCHEEL-YBERT, R.; CAROMANO, C.F.; CASCON, L.M.; BIANCHINI, G.F.; BEAUCLAIR, M. Estudos de paleoetnobotânica, paleoambiente e paisagem na Amazônia Central e o exemplo do sudeste-sul do Brasil. In: Pereira E; Guapindaia V (eds.)

Arqueologia Amazônica. Vol. 2. Belém: Museu Paraense Emílio Goeldi. 909-935p. 2010.

SCHEEL-YBERT, R.; KLÖKLER, D.; GASPAR, M.D.; FIGUTI L. Proposta de amostragem padronizada para macro-vestígios bioarqueológicos: antracologia, arqueobotânica, zooarqueologia. Rev. do Museu de Arqueologia e Etnologia, São Paulo, 15-16: 139-163. 2005-2006.

SCHEEL-YBERT, R.; SOLARI, M.E.; FREITAS, F.O. Arqueobotânica: Integrando indícios sobre meio ambiente, uso de vegetais e agricultura à Arqueologia. 2003. Available in: <http://www.arqueologia.mn.ufrj.br/docs/papers/rita/SAB2003etal.pdf>. Access: 03-08-2012.

SCHMIDT, E.O. Avaliação antracológica de fragmentos de carvão vegetal fóssil em porçóes do sítio arqueológico RS T 114: um estudo multidisciplinar para a determinação de histórico ambiental. Masters Dissertation Univates. 2010.

SCHNEIDER, P. Cozer, guardar e servir: a cultura material do cotidiano no sítio pré-colonial RS T 101 - Marques de Souza/RS. Graduate Thesis, Univates, Lajeado,75 p. 2008.

SCHWEINGRUBER, F.H. Mikroskopische Holzanatomie, Komisionverslag. In: F. Flück-Wirth (Ed.). Internationale Buchhandlung für Botanik und Naturwissenschaften, CH-9053 Teufen AR. 1982.

SECCHI, M.I. Avaliação antracológica em sítios pré-coloniais como ferramenta para a análise da História Ambiental da Bacia Hidrográfica do Rio Forqueta, Rio Grande do Sul, Brasil. Masters Dissertation - Univates, Brazil. 83p. 2012.

SHACKLETON, C.M.; PRINS, F. Charcoal analysis and the "Principle of Least Effort" a conceptual model. Journal of Archaeological Science 19, 631-637. 1992.

SCOTT, A.C. Observations on the nature and origin of fusain. Inter. Journ. Coal Geol. 12: 443-475. 1989 .

SCOTT, A.C. The pre-quaternary history of fire. Palaeo 3, 164, p. 281-329. 2000.

SCOTT, A.C. Fossil Charcoal recognition, taphonomy and uses in palaeoenvironmental analysis. Palaeo 3, 291, p. 11-39. 2010. 
SCOTT, A.C.; GLASSPOOL, I. Observations and experiments on the origin and formation of inertinite group macerals. Inter. Journ. Coal Geol., v. 70, p. 53-66. 2007.

TERESO, J.P.V. Paleoetnobotânica do povoado romano da Terronha de Pinhovelo (NE transmontano). Masters Dissertation - Universidade do Porto. 2007.

THÉRY-PARISOT, I. Économie du combustible au Paléolithique. Anthracologie, Expérimentation, Taphonomie. In: Dossier de Documentation Archéologique, 20. C.N.R.S., Paris. 2001.

VERNET, J.L. (Org.). Les charbons de bois, les anciens écosystèmes et le rôle de l'homme. Bulletin de la Société Botanique de France. Actuallités botaniques. Paris, v.139, n. 2/3/4. Comptes'rendus colloques. 1992.

WATANABE, S.; MUNITA, C.; GENNARO, R.; ALPENDRE, F.; MACHADO, N.T.G. Archeometry research on the Taquari Valley. In: XV Congresso da Sociedade de Arqueologia Brasileira, Belém. Anais do XV Congresso da Sociedade de Arqueologia Brasileira. 2009.

WHEELER, E.A.; BAAS, P.; GASSON, P.E. Iawa List of Microscopic features for hardwood identification. Iawa Bulletinn. s. 10 (3): 219-332 p. International Association of Wood Anatomists at the National Herbarium of the Netherlands, Leiden. 1989.

WOLF, S. Um espaço na pré-história do Vale do Taquari. Graduate Thesis - Univates, Brazil. 2010.

WOLF, S. Paisagens e sistemas de assentamento: um estudo sobre a ocupaçáo humana pré-colonial na bacia hidrográfica do Rio Forqueta/RS. Masters Dissertation - Univates. Brazil. 2012. 